\title{
IMPLEMENTASI PEREMPUAN TERHADAP PENDIDIKAN ANAK USIA DINI
}

\author{
Rina Hizriyani \\ Universitas Muhammadiyah Cirebon,Indonesia \\ rinahizriyani@yahoo.com
}

\begin{abstract}
A woman is a mother who plays a major role in shaping the character, character and personality of her children. He is the first and primary school before children receive education in any school. But not a few mothers who think, when children have entered school, the school is responsible for education. Though the role of the mother can not be replaced by anyone. Mothers have more roles than schools, namely developing children's emotional intelligence and even building children's spiritual intelligence. The role of women has always been an interesting subject, including in education. In Islam, a woman has the same gait as a man in terms of education. Every Muslim and Muslim woman have the same obligation in seeking knowledge and equipping themselves with various kinds of knowledge needed in life. In a hadith Rosulullah said, which means "Demanding compulsory knowledge for every Muslim" (HR. Ibnu Adi and Baihaqi). The Prophet has given special attention to Muslim education. He set aside a special time to educate and answert heirquestions,Muslim women.
\end{abstract}

Keywords: Implementation, Women, Children's Education

Abstrak

Seorang Perempuan adalah ibu yang berperan besar dalam pembentukan watak, karakter dan kepribadian anak-anaknya. Ia adalah sekolah pertama dan utama sebelum anak mengenyam pendidikan di sekolah manapun.Namun tidak sedikit ibu yang beranggapan, ketika anak sudah masuk sekolah maka sekolahlah yang bertanggung jawab atas pendidikannya. Padahal peran ibu tidak bisa tergantikan oleh siapapun. Ibu memiliki peran lebih dari sekolah yakni membangun kecerdasan emosional anak bahkan membangun kecerdasan spiritual anak.Peran wanita selalu menjadi bahasan menarik, termasuk di dunia pendidikan. Dalam Islam, seorang wanita memiliki kiprah yang sama dengan laki-laki dalam hal pendidikan. Setiap muslim maupun muslimah mempunyai kewajiban yang sama dalam mencari ilmu dan membekali dirinya dengan berbagai macam ilmu yang dibutuhkan dalam kehidupan. Dalam sebuah hadits Rosulullah bersabda, yang atinya " Menuntut ilmu wajib bagi setiap muslim" (HR. Ibnu Adi dan Baihaqi). Rosulullah telah memberikan 
perhatian khusus terhadap pendidikan muslimah. Beliau menyisihkan waktu khusus untuk mendidik dan menjawab pertanyaan mereka, para muslimah.

Kata Kunci : Implementasi, Perempuan, Pendidikan Anak

\section{A. Pendahuluan}

Kemajuan sebuah bangsa tidak bisa dipisahkan dari bangkitnya dunia pendidikan. Pendidikan adalah kebutuhan setiap bangsa. Bahkan dalam ranah keluarga, pendidikan mutlak menjadi satu hal yang utama. Pendidikan adalah salah satu sarana untuk membentuk sebuah kepribadian Islam, yang berlaku seumur hidup. Dimulai sejak anak dilahirkan, hingga akhir hayat. Dari buaian hingga liang lahat.

Dalam Islam, wanita adalah kehormatan yang wajib dijaga. Banyak sekali hukum syariat Islam yang menunjukkan pemuliaan dan penghormatan pada wanita. Auratnya diminta untuk dijaga dengan kewajiban mengenakan hijab sehingga nampaklah kemuliaannya. Seorang wanita tidak diwajibkan bekerja dan mencari nafkah karena dia harus dinafkahi oleh ayah atau suami. Harta waris bagi wanita adalah mutlak buat dirinya sendiri dan tidak wajib diberikan kepada suami dan anak-anak. Dalam bidang pendidikan, wanita mempunyai hak sekaligus kewajiban untuk mengakses ilmu pengetahuan serta mengajarkannya. Dengan demikian, Islam telah memberi kesempatan bagi laki-laki juga wanita mendulang pahala dari pelaksanaan kewajiban menuntut ilmu.

Ibu adalah "gudang ilmu", "pusat peradaban" dan "wadah" yang menghipum sifatsifat akhlak mulia. Peran yang sangat penting ini, meuntut seorang ibu untuk membekali dirinya dengan ilmu yang memadai. maka seorang ibu harus terus bergerak meningkatkan kualitas dirinya. Karena, untuk mencetak generasi yang berkualitas, diperlukan pendidik yang berkualitas pula. Hal itu berarti ibu tak boleh berhenti belajar.

Sebagai sekolah pertama, seorang ibu berperansebagai pendidik anak. Dari ibulah seorang anak belajar tentang segala hal baru dalam hidupnya. Belajar berbicara, menimba ilmu dan adab yang mulia, serta menempa kepribadiannya demi mengarungi kehidupan yang luas bagai samudera. Maka sungguh beruntung bagi seorang ibu yang senantiasa 
meluangkan waktunya untuk anak-anaknya, demi tercapainya impian menjadi anak- anak shalih-shalihah.

Di dalam Islam, seorang perempuan yang telah menjadi ibu harus mampu menjadi pendidik yang baik sejak anaknya di dalam kandungan atau dikenal dengan pendidikan pranatal. Di sini seorang ibu harus menjaga seluruh tingkah laku dan ucapannya, karena sangat berpengaruh terhadap karakter si janin yang akan lahir ke dunia.

Setelah anak tersebut lahir, hal yang harus dilakukan seorang ibu mengajarkannya akidah dan tauhid, yaitu kepercayaan terhadap Allah SWT. Jika tauhid sudah tertanam sejak dini, maka anak tersebut akan tumbuh dengan karakter yang kuat. Didikan yang baik dan kasih sayang yang cukup, serta pemenuhan materi harus ada keseimbangan dalam mendidik anak-anak, sehingga anak tumbuh dengan kepercayaan yang tinggi terhadap orang tua.

Perempuan memiliki peranan penting dalam pendidikan untuk mencetak generasigenerasi emas penerus bangsa. Maka, perempuan harus mengupayakan diri untuk menjadi perempuan yang pintar sebagai bekal untuk mendidik anak-anaknya, karena seorang ibu cerdas akan melahirkan anak-anak yang cerdas dan kecerdasan tidak dapat diperoleh kecuali dengan proses belajar.

Dari latar belakang di atas maka identifikasi masalah adalah kurangnya pendidikan perempuan dalam hal ini seorang ibu dalam mendidik anak terutama anak0anak yang masih berada pada usia dini. Berdasarkan latar identifikasi permsalahan dia atas maka rumusan masalah penelitian ini adalah bagaimana implemetasi seoranmg perempuan terhadap Pendidikan Anak Usia Dini. Tujuan Peneltiian ini tidak lain adalah dapat mengetahui implementasi perempuan terhadap pendidikan anak usia dini/

\section{B. Peran Ibu dalam Pendidikan Anak}

Tugas dan tanggung jawab ibu begitu besar. Bukan hanya mengasuh tapi juga mendidik."ibu adalah madrasah pertama bagi anak'. Ibu adalah sekolah utama, bila 
engkau mempersiapkannya, maka engkau telah mempersiapkan generasi terbaik.Ibu berperan besar dalam pembentukan watak, karakter dan kepribadian anak-anaknya. Salah satu peran ibu adalah mendidik. Mendidik anak bukanlah pekerjaan yang mudah. Banyak sekali hambatan dan rintangan dalam proses perjalanannya. Oleh karena itu seorang ibu harus berbekal dengan kesabaran dan ketawakkalan, dengan sabar dan tawakkal dalam mendidik buah hati, akan memperoleh hasil yang maksimal.

Pengetahuan yang pertama kali di kenalkan ke anak-anak kita adalah seputar tauhid, yakni upaya sang anak untuk mengetahui dan meyakini akan Tuhan semesta alam. Mereka harus memahami siapa yang memberinya kehidupan, yang menciptakan mereka.Akidah merupakan factor yang paling urgen dalam kehidupan ini. Wajar saja jika Islam lebih memprioritaskannya. Karena iman merupakan fundamental sekali. Oleh karenanya, dilandasi oleh akidah yang kuat, anak kan mengerti akan kebenaran dan benteng akidah tidak akan goyah begitu saja di tengah liarnya aliran yang muncul ke permukaan.

Seorang ibu harus menjadi figur yang baik di mata anak-anaknya. Sosok yang harus selalu memberikan contoh yang baik dengan cara selalu menemani dan menjadi tempat bersandar bagi anak-anaknya untuk mencurahkan isi hati dan pikirannya. Kedekatan emosional antara ibu dan anak inilah yang harus dibangun agar dapat menghantarkan anakananya menuju kesuksesan.

Menjadi seorang ibu juga harus bisa menanamkan sikap mandiri kepada anak-anak. Sikap inilah yang akan menjadikan anak hidup tidak bergantung pada orang lain. Sikap berani mengambil keputusan juga harus diterapkan sedini mungkin. Tidak lupaseorang ibu harus mengarahkan dan memotivasi atas pilihan yang telah ditentukan oleh anakanaknya.Keluarga adalah unit terkecil di dalam masyarakat yang akan menentukan mutu dari masyarakat. Negara akan bermutu kalau keluarga juga bermutu dan sakinah. Semua itu tidak tercapai kalau pendidikandi dalam keluarga tidak berjalan dengan baik.Pendidikan di dalam keluarga harus dilandasi dengan nilai-nilai agama. Nilai-nilai Islam itu harus ditanamkan ke dalam diri anak-anak, baik melalui lisan maupun perbuatan. 
Peranan ibu sebagai teladan bagi anaknya bertujuan agar ibu mampu menjadi contoh bagi anak-anaknya. Mengingat bahwa perilaku orang tua, khususnya ibu, akan ditiru yang kemudian dijadikan panduan dalam perilaku anak. Ibu harus mampu menjadi teladan bagi mereka. Dalam hal ini yang harus diperhatikan oleh orang tua dalam mendidik anak adalah proses mendidik yang disesuaikan tingkat perkembangan anak itu sendiri. Perkembangan anak usia 0-5 tahun memiliki perkembangan yang berbeda, karena terbatas oleh inderawinya saja. Akal pikiran dan perasaannya belum berfungsi secara maksimal.

Berdasarkan tingkah laku ibunya itulah, anak akan senantiasa meniru, kemudian menerapkannya dalam kehidupan. Dalam paerkembangan anak, proses identifikasi sudah mulai bisa dilakukan ketika anak berusia 3-5 tahun.

\section{Potensi dan Kontribusi Perempuan dalam Pendidikan}

Seorang Ibu memiliki peluang dan peranan yang besar dalam mendidik anak. Bahkan dimulai dari mendidiknya didalam kandungan, hingga usia pra baligh. Pada masa emas itu, kondisi keluarga dan lingkungan yang diciptakan oleh seorang ibu akan membawa dampak besar bagi perkembangan anak. Al Qur'an yang diperdengarkan ketika masih dalam kandungan, suara adzan dan iqomah dari ayah yang didengar pertama kali dia bisa mendengar, dan suara seorang Ibu menyambut kehadirannya di dunia, sangatlah berpengaruh dalam berjalannya proses pendidikan selanjutnya.

Ibulah yang bertanggung jawab menciptakan suasana kondusif penuh keimanan kepada anak di masa pra balighnya. Dan itulah pendidikan dasar yang akan menentukan corak kepribadian anak. Ibarat kertas putih, maka orang tuanya, terutama seorang ibulah yang akan memberi warna dasar pada kepribadian anan-anak. Seorang ibu yang berperilaku kurang baik, akan menghasilkan warna yang tak jauh berbeda dengan dirinya. Untuk itu, seorang ibu harus cerdas dan berkepribadian Islam yang tinggi. Dia harus menanamkan sifat mulia dan nilai-nilai Islam yang tinggi. Karena di masa emas, otak anak ibarat radar, yang akan menyerap suara, informasi dan perilaku apapun dari yang terdekat, yaitu sang ibu serta lingkungan keluarga. 
Anak balita memiliki tingktat kecerdasan yang cukup tinggi untuk menagkap sesuatu di lingkungannya. Kepekaan dan daya tangkap yang dimiliknya mampu menirukan apa yang dilihat olehnya. Perilaku yang baik dari orang tua dalam keseharian bisa menjadi factor utama dalam pengembangan karakter dan kpribadian yang baik si balita.

Akhlak merupakan sebuah karakter yang melekat dalam hati, kebiasaanlah yang akan membentuknya. Maka, kondisi yang harmonis dalam lingkungan keluarga diharapkan sekali demi terbentuknya senerasi yang bermoral dan bermartabat.

Seorang ibu harus mampu mendidik anak-anak dengan landasan cinta dan kasih sayang yang benar. Rasa cinta yang benar adalah yang mendahulukan rasa cinta kepada Allah dan RosulNya diatas segalanya. Dengan demikian, rasa cinta kepada anak tidak menghalangi seorang ibu untuk mendidik anaknya menjadi seorang yang berguna bagi agama dan sesama.

Selain dalam lingkup terbatas keluarga, seorang perempuan mempunyai peluang dan peran cukup besar di lingkungan masyarakatnya. Seorang ibu mempunyai tanggung jawab yang besar dalam mengawal proses pendidikan anak-anaknya. Bagaimana mereka bisa mengawal anak-anaknya ketika dalam dirinya tidak ada ilmu yang memadai. Ketika seorang ibu harus mendidik anak-anaknya.

Ibu juga berperan sebagai motivator, pemberi motivasi bagi kelangsungan kehidupan anak. Sejak masa kelahiran seorang anak, proses pertumbuhan berbagai organ belum sepenuhnya lengkap. Perkembangan organ-organ ini ditentukan oleh motivasi rangsangan yang diterima anak dari ibunya. Rangsangan yang diberikan oleh ibu akan memperkaya pengalaman dan mempunyai pengaruh yang besar bagi perkembangan kognitif anak. Bila pada bulan-bulan pertama anak kurang mendapatkan stimulasi visual, perhatian terhadap lingkungan sekitar juga akan berkurang.

Stimulasi verbal dari ibu akan sangat memperkaya kemampuan bahasa anak, baik dari kualitas maupun kuantitasnya. Kesediaan ibu untuk berbicara dengan anaknya akan 
mengembangkan proses bicara anak. Jadi perkembangan mental anak akan sangat ditentukan oleh motivasi stimulasi rangsangan yang diberikan ibu terhadap anaknya. Bentuk rangsangan dapat berupa cerita-cerita, alat permainan yang edukatif, atau bisa juga mengajak anak berekreasi, sehingga dapat memperkaya pengalamannya. Dalam hal ini sosok ibu dituntut untuk terus meningkatkan kualitas dirinya dengan memperkaya sebanyak mungkin ilmu pengetahuan, teknologi, dan seni sebagai modal awal dalam rangka keberhasilannya dalam memberi motivasi agar kehidupan anak yang cerdas serta sukses tercapai.

Kontribusi Ibu dalam pendidikan anak memiliki peran yang sangat penting terutama pada awal-awal masa balita. Keberhasilan pendidikan anak sangat ditentukan oleh ibu, meskipun keikutsertaan ayah tidak dapat diabaikan begitu saja karena keluarga menjadi lingkungan social terpenting bagi perkembangan dan pembentukan pribadi anak serta menjadi tempat bimbingan dan latihan anak dalam kehidupan mereka.

\section{Peran Ibu Dalam Keluarga}

Peranan ibu sebagai pemenuh kebutuhan bagi anak sangat penting, terutama ketika berusia 0 - 5 tahun. Pada saat itu, anak sangat bergantung pada ibu. Kemudian ketergantungan itu tetap berlangsung sampai dengan periode anak sekolah. Bahkan menjelang dewasa. Ibu perlu menyediakan waktu bukan saja untuk selalu bersama, tetapi juga untuk berinteraksi atau berkomunikasi secara terbuka dan timbal balik dengan anaknya. Pendidikan yang didapat anak dalam keluarga meliputi pendidikan iman, moral, fisik jasmani, intelektual, psikologi dan social.

Kehidupan dalam keluarga merupakan titik awal untuk menuju kehidupan bernegara. Anak yang terlahir dalam keluarga yang terdidik tentu akan berbeda nilainya dibandingkan anak tanpa perhatian orangtuanya, khususnya ibu. Hal ini karena secara psikologis perempuan memiliki sifat kasih sayang yang tinggi.

Secara alami anak-anak pada masa awal kehidupannya bersama ayah dan ibunya.Dari keduanya, mereka mengenal pendidikannya, dasar pandangan hidup, sikap 
hidup danketerampilan hidup banyak tertanam sejak anak berada di tengah orang tua.(Ramayulis:2017.85)

Dalam memenuhi kebutuhan psikis anak, seorang ibu harus mampu menciptakan situasi yang aman bagi putra-putrinya. Ibu diharapkan dapat membantu anak apabila mereka menemui kesulitan-kesulitan. Perasaan aman anak yang diperoleh dari rumah akan dibawa keluar rumah. Artinya anak tidak akan mudah cemas dalam menghadapi masalahmasalah yang timbul. Dengan demikian, perkembangan kepribadian anak bermula dari keluarga, kemudian anak mengambil nilai-nilai yang ditanamkan orang tuanya, baik secara sadar maupun tidak. Dalam hal ini orang tua hendaknya menjadi contoh yang positif bagi anaknya.

Mengenai kewajiban perempuan dalam keluarga, yang utama adalah mengaturrumah tangga, termasuk di dalamnya menerima kepemimpinan suami atau mentaatinya,mendidik anak-anaknya agar menjadi shalih dan shalihah, dan sebagainya. Hal ini sesuaidengan teori yang menyatakan bahwa perempuan berkewajiban untuk mendidik,maksudnya perempuan shalihah yang berperan sebagai ibu dalam keluarga, berarti berkewajiban untuk mendidik anak-anaknya.

Seto Mulyadi (2007 : 20) menegaskan kekuatan persekolahan di rumah adalah lebih memberikan kemandirian dan kreatifitas bagi anak, meningkatkan peluang untuk mencapai kompetensi individual secara maksimal, terlindungi dari penyakit sosial seperti narkoba, konsumerisme, pergaulan menyimpang dan tawuran, serta memungkinkan anak siap menghadapi kehidupan nyata dengan lingkup pergaulan yang lebih luas, serta mempercepat tercapainya masyarakat belajar yang merupakan salah satu ciri masyarakat madani. Yang terpentingadalah peranan perempuan menjadi lebih dapat ditingkatkan. Ini dibuktikan darisebagian besar pendidik dan pegiat home schooling adalah perempuan.

Peranan perempuan terutama sebagai seorang ibu perlu ditingkatkan dalammenunjang keberhasilan pendidikan formal anak di sekolah. Beberapa tokohdunia seperti Thomas Alfa Edison berhasil menjadi penemu besar justru lewatdidikan dasar dari sang ibu. Tokoh besar 
ini dianggap gagal menempuhpendidikan formal, akan tetapi justru berhasil lewat didikan ibunya yang mendidikdengan tekun di rumah. Banyak kasusmembuktikan keberhasilan seseorang tidak hanya ditentukan oleh kecerdasanintelektual (IQ) saja, namun banyak kecerdasan lain yang lebih banyakdikembangkan oleh lingkungan sekitar terutama ibu sebagai pendidik dasar kepribadian anak.

\section{E.Simpulan Dan Saran}

Kehidupan dalam keluarga merupakan titik awal untuk menuju kehidupan bernegara. Anak yang terlahir dalam keluarga yang terdidik tentu akan berbeda nilainya dibandingkan anak tanpa perhatian orangtuanya, khususnya ibu. Hal ini karena secara psikologis perempuan memiliki sifat kasih sayang yang tinggi.

Wanita adalah guru pertama bagi sang anak, sebelum dididik orang lain. Sejak ruh ditiupkan ke dalam rahim, proses pendidikan sudah dimulai. Sebab mulai saat itu, anak telah mampu menangkap rangsangan-rangsangan yang diberikan oleh ibunya. Ia mampu mendengar dan merasakan apa yang dirasakan ibunya. Bila ibunya sedih dan cemas, ia pun merasakan demikian. Sebaliknya, bila ibunya merasa senang, ia pun turut senang.

Ketika anak terlahir ke muka bumi, ia sudah berusaha memahami apa yang diajarkan oleh seorang ibu. Ketika kata pertama keluar dari seorang bayi, kata itu akan diterjemahkan oleh sang ibu. Sehingga anak mengetahui apa yang diucapkan itu memiliki arti. Anak meniru apa yang baik dan buruk dari ibunya serta menyaring segala sesuatu yang ada di luar rumah lewat ibunya. Bila seorang ibu membiasakan anaknya dari kandungan sampai dewasa dengan adab-adab Islam, ia pun akan terbiasa dengan hal itu. Tapi sebaliknya, bila ibu membiasakan dengan adab - adab yang tidak Islami, ia pun akan ikut seperti ibunya.

Wanita mempunyai peran penting dalam pendidikan dan pembentukan pribadi anak. Meskipun peran tersebut bersifat abstrak, namun sangat signifikan untuk mencetak generasi yang cerdas dan berakhlak. 


\section{Daftar Pustaka}

Amani Ar-Ramadi,(2016), Pendidikan Cinta untuk Anak, Aqwam, Solo

Ramayulis,(2017),Psikologi Agama, Kalam Mulia, Jakarta

Seto Mulyadi,(2017), Psikologi Pendidikan dengan pendekatan teori-teori baru dalam psikologi, Rajawali pers, Yogyakarta .

https://lenterakeluarga.com/peran-ibu-dalam-pendidikan-anak

https://muslimahactivity.wordpress.com/2017/11/25/peran-ibu-dalam-mendidik-anak/

https://muslimah.or.id/6248-peran-ibu-dalam-pendidikan-anak.html

https://www.sarihusada.co.id/Nutrisi-Untuk-Bangsa/Tips-si-Kecil/Peran-Ibu-DalamMendidik- Dan-Membangun-Karakter-Anak 